\title{
PEMBELAJARAN IPA DENGAN PRAKTIKUM BERBASIS KONTEKS DAN LITERASI SAINS: PERSPEKTIF GURU SD DI SUKABUMI
}

\author{
Sistiana Windyariani \\ Program Studi Pendidikan Biologi, Universitas Muhammadiyah Sukabumi \\ J1. R. Syamsudin SH No 50, Sukabumi \\ E-mail: windyariani@gmail.com
}

\begin{abstract}
Laboratory activities are important of science learning at any level. At the elementary school lab work needs to be done in the context of daily life in order to training scientific literacy. This study aims to determine how the teacher's perspective on science teaching in primary schools in Sukabumi, West Java in the academic year 2015/2016. Research methods such as survey, data analysis quantitatively and qualitatively. Data collection used is a kuosioner sheet and interview guides to explore the teacher's perspective grade 4 and 5 primary school in implementing and understanding the context-based practicum. The results showed all the teachers (100\%) stated the laboratory activities is important to be implemented, but most of the teachers (75\%) stated the laboratory activities difficult to implemented. Teachers argued do not understand the practicum as an activity that can be done simply based on the context of everyday life in an effort to train science literacy (97\%). The results of the elementary teacher's perspective is able to provide precise information about the condition of learning science as a material improvement regarding practical learning becomes more meaningful.
\end{abstract}

Keywords: practical laboratory, context, Scientific Literacy

Pembelajaran hendaknya diarahkan untuk mengembangkan individu yang berliterasi sains (scientifically literate). Literasi sains begitu penting dan menjadi kebutuhan setiap individu karena kemampuan literasi sains suatu negara berhubungan erat dengan tingkat ekonomi di negara tersebut (Phearson, 2008).

Menurut penelitian Noris dan Philips (2003), hal penting yang harus diperhatikan untuk melatihkan literasi sains adalah pembelajaran yang dilakukan tidak hanya berupa diskusi serta presentasi, melainkan mengharuskan guru untuk lebih kreatif untuk mengembangkan pertanyaan yang berbasis masalah yang akan dipecahkan melalui metode ilmiah. Penerapan metode ilmiah dalam pembelajaran sebetulnya bukanlah hal yang baru, pembelajaran yang mengutamakan penalaran ilmiah sesungguhnya telah menjadi pusat perhatian dan kajian para ahli pada 
pembelajaran sains dasar atau sains terintegrasi selama lebih dari 3 dekade (Harlen, 1999, Brotheron \& Preece, 1995).

Praktikum adalah bentuk manifestasi dan strategi pembelajaran yang dapat menuntut siswa untuk dapat menggunakan pengetahuan yang telah didapat dari proses ilmiah. Berbagai materi praktikum pada umumnya mengungkap fakta-fakta sains maupun teori sains, namun sangat disayangkan sebagian besar praktikum hanya dilakukan melalui tahap kegiatan yang sudah terperinci dan tinggal diikuti siswa seperti halnya resep makanan (Sumintono, 2001)

Kegiatan praktikum pada pembelajaran IPA seharusnya dilakukan pada setiap level pendidikan, terutama harus mulai diterapkan pada siswa di level sekolah Dasar (SD). SD merupakan tempat formal pertama kali siswa mendapatkan pembelajaran sains, sehingga menjadi waktu yang tepat bagi siswa untuk belajar sains agar memiliki konsep sains yang kuat di usia dini.

Menurut tingkat

perkembangan kognitif Piaget siswa usia SD kelas 4 dan 5 berada pada tahap operasi konkret (concrete operation) (Suparno, 2001). Pada tahap ini anak sudah mampu mengembangkan pemikiran logis yang dapat diterapkan untuk memecahkan persoalan konkret yang dihadapi. Kecenderungan pemikiran siswa usia tahap operasi konkret akan sulit jika langsung dihadapkan pada materi yang abstrak, namun akan mampu memecahkan permasalahan yang dekat dengan konteks yang sering ditemukan sehari-hari.

Pada pembelajaran berbasis konteks, konteks digunakan sebagai titik awal untuk mengembangkan pemikiran ilmiah (Bennett, Lubben \& Hogarth, 2006; Ramsden, 1997). Tujuan utama dari pendekatan berbasis konteks adalah untuk menyajikan konsep ilmiah untuk siswa melalui kegiatan di kehidupan sehari-hari yang dipilih, yang mampu meningkatkan motivasi mereka sehingga tertarik untuk belajar sains (Barker dan Millar, 1999; Kose dan Tosun, 2011).

Penelitian ini bertujuan untuk mengkaji bagaimana perspektif guru SD dalam melaksanakan pembelajaran IPA berbasis konteks untuk melatihkan literasi sains. Hodson (1993) mengemukakan bahwa pemahaman siswa tentang sains akan selalu konsisten dengan pandangan gurunya. Begitupun dengan pemahaman guru terhadap bagaimana melaksanakan praktikum secara baik, persepsi guru terhadap pelaksanaan praktikum akan memberikan dan bagaimana praktikum mampu melatihkan literasi sains.

Berdasarkan latarbelakang yang telah dikemukakan perlu diketahui perspektif guru mengenai pembelajaran praktikum berbasis konteks yang akan memberikan indikasi tentang kondisi pembelajaran IPA yang sesungguhnya berkaitan dengan pelaksanaan praktikum yang sesuai di tahap siswa usia sekolah dasar dalam upaya melatihkan literasi sains. 


\section{METODE}

Penelitian ini menggunakan metode survei dengan pendekatan kualitatif dan kuantitatif. Metode kuantitatif digunakan melalui penyebaran instrumen lembar kuosioner kepada responden kemudian ditabulasi dan dihitung persentase total dari jawaban yang diberikan dan dikategorisasi menurut Koentjaraningrat (1994). Metode kualitatif berupa wawancara kepada guru-guru dengan menggunakan pedoman wawancara.

Penelitian melibatkan 16 Sekolah Dasar di Kota Sukabumi Jawa Barat yang dilaksanakan pada bulan Mei-Juni 2016. Dari 16 Sekolah guru yang terlibat dalam penelitian ini sebanyak 32 yakni yang berasal dari perwakilan guru-guru kelas 4 dan 5 . Guru mengisi kuosioner mengenai perpektif terhadap pembelajaran praktikum berbasis konteks. Kemudian dilanjutkan dengan mewawancarai guru untuk menggali lebih mendalam mengenai pendapatnya tentang praktikum berbasis konteks. Adapun data responden yang mengisi kuosioner berupa jenis kelamin dan usia disajika pada tabel 1 berikut.

Tabel 1. Data Responden kuesioner

\begin{tabular}{lc}
\multicolumn{2}{c}{$(\mathrm{N}=32)$} \\
\hline \multicolumn{1}{c}{ Deskripsi } & \% \\
\hline Jenis kelamin & \\
Laki-laki & 62 \\
Perempuan & 38 \\
\hline Kelompok usia (tahun) & \\
$20-29$ & 16 \\
$30-39$ & 38 \\
$40-49$ & 28 \\
$>49$ & 19 \\
\hline
\end{tabular}

\section{HASIL DAN PEMBAHASAN}

Hasil dari pengisian kuosioner mengungkap perspektif guru mengenai kegiatan praktikum berbasis konteks dan literasi sains. Adapun hasil dari kuosioner disajikan pada tabel 2 berikut ini.

Tabel 2. Rincian hasil kuosioner

\begin{tabular}{|c|c|}
\hline Deskripsi & $\%$ \\
\hline $\begin{array}{l}\text { Pentingnya praktikum untuk } \\
\text { dilaksanakan }\end{array}$ & \\
\hline Ya & 100 \\
\hline Tidak & 0 \\
\hline \begin{tabular}{llr} 
Berapa kali & \multicolumn{2}{c}{ praktikum } \\
dilaksanakan & pada & satu \\
semester & &
\end{tabular} & \\
\hline 0 & 22 \\
\hline 1 & 59 \\
\hline $2-3$ & 13 \\
\hline $4-5$ & 6 \\
\hline$>5$ & 0 \\
\hline $\begin{array}{lll}\text { praktikum } & \text { sulit } & \text { untuk } \\
\text { dilaksanakan } & & \end{array}$ & \\
\hline Ya & 75 \\
\hline Tidak & 25 \\
\hline \begin{tabular}{lrr} 
Faktor yang & \multicolumn{2}{c}{ menyebabkan } \\
praktikum & sulit & untuk \\
dilaksanakan & &
\end{tabular} & \\
\hline $\begin{array}{l}\text { menyiapkan alat dan bahan } \\
\text { praktikum }\end{array}$ & 33 \\
\hline mengkondisikan siswa & 22 \\
\hline waktu yang terbatas & 6 \\
\hline $\begin{array}{l}\text { Fasilitas yang kurang memadai } \\
\text { (laboratorium, alat dan bahan) }\end{array}$ & 59 \\
\hline $\begin{array}{l}\text { Kategori materi yang } \\
\text { dipraktikumkan }\end{array}$ & \\
\hline $\begin{array}{l}\text { Fisika (gaya, magnet, listrik, } \\
\text { energi) }\end{array}$ & 63 \\
\hline $\begin{array}{l}\text { Kimia (materi, tegangan } \\
\text { permukaan, perubahan sifat) }\end{array}$ & 12 \\
\hline $\begin{array}{l}\text { Biologi (sistem pernafasan, } \\
\text { transport pada batang) }\end{array}$ & 25 \\
\hline $\begin{array}{l}\text { Mengetahui tentang literasi } \\
\text { sains }\end{array}$ & \\
\hline Ya & 28 \\
\hline Tidak & 72 \\
\hline \begin{tabular}{ll} 
Melaksanakan & \multicolumn{2}{c}{ praktikum } \\
berdasarkan masalah yang
\end{tabular} & \\
\hline
\end{tabular}




\begin{tabular}{lc}
\hline $\begin{array}{l}\text { siswa temukan pada kehidupan } \\
\text { sehari-hari (bukan berdasarkan }\end{array}$ & \\
$\begin{array}{l}\text { konten materi) } \\
\text { Pernah }\end{array}$ & 6 \\
Tidak pernah & 97 \\
\hline Acuan/sumber untuk & \\
melaksanakan praktikum & \\
Buku teks & 42 \\
LKS yang sudah ada dari penerbit & 35 \\
LKS yang disusun sendiri & 6 \\
Internet & 17 \\
\hline
\end{tabular}

Selain dari lembar kuosioner, data diperoleh dari hasil wawancara kepada guru-guru. Lembar wawancara terdiri dari 3 pertanyaan yang relevan dengan kuosioner. Adapun data hasil wawancara tersaji pada grafik 1-3. Grafik 1 menunjukkan persentase jawaban berdasarkan wawancara mengenai pentingnya kegiatan praktikum.

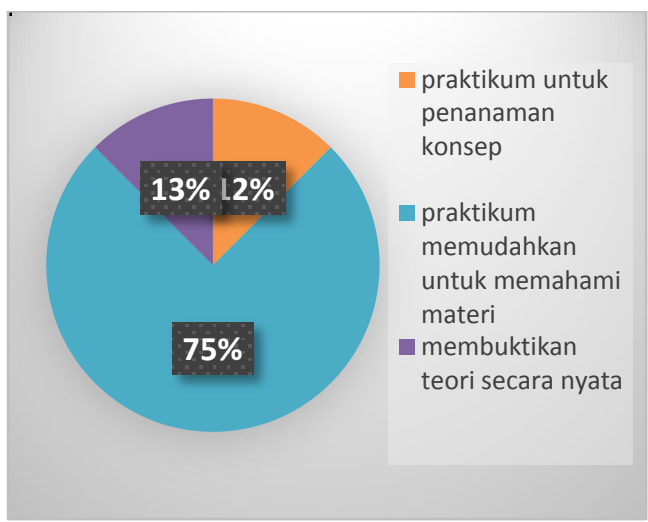

Grafik 1. Persentase jawaban guru mengenai pentingnya kegiatan praktikum

Pada Tabel 2 diperoleh hasil dari kuosioner seluruh guru $(100 \%)$ menganggap bahwa praktikum penting untuk dilaksanakan. Adapun jawaban ini diperkuat dengan hasil yang diperoleh dari wawancara mengenai alasan para guru mengenai pentingnya kegiatan praktikum. Rekapitulasi wawancara keseluruhan dapat dilihat dari grafik 1 dengan hasil: praktikum memudahkan memahami materi $(75 \%)$, praktikum membuktikan teori secara nyata (13\%) dan praktikum untuk menanamkan konsep (12\%). Adapun contoh komentar guru diberi kode $\mathrm{G}$ dan nomor urut guru. Komentar guru yang banyak yakni "Dengan praktikum akan lebih mudah untuk memahami materi (G5, G8, G13, G22)".

Semua guru yang terlibat dalam penelitian ini menganggap bahwa praktikum penting untuk dilakukan dalam pembelajaran IPA di SD. Namun berdasarkan hasil wawancara mengenai alasan pentingnya kegiatan praktikum belum cukup dipahami oleh para guru. Guru beranggapan bahwa praktikum untuk membuktikan teori, memudahkan memahami materi dan penanaman konsep, artinya pemahaman guru terhadap praktikum masih sebatas praktikum dapat menunjang materi pembelajaran. Padahal menurut Yelon (Rustaman, 2010) praktikum mengembangkan keterampilan dasar, membangkitkan motivasi belajar, wahana belajar pendekatan ilmiah, serta mampu memfasilitasi kreativitas. Perspektif guru akan pentingnya praktikum juga belum memahami bahwa esensi dari hakikat sains adalah inkuiri. Inkuiri dalam pembelajaran sains merupakan alat untuk mengembangkan kepribadian dan sikap ilmiah.

Sejalan dengan pendapat Yelon dalam Rustaman (2011), bahwa belajar sains tidak hanya sekedar belajar informasi sains tentang fakta, konsep, prinsip, hukum, akan tetapi belajar sains juga belajar tentang cara memperoleh informasi 
sains dalam bentuk pengetahuan prosedural dengan metode ilmiah dan sikap ilmiah. Lebih lanjut bahwa tujuan pembelajaran sains di SD yang ditetapkan oleh BSNP (2006) adalah untuk mengembangkan rasa ingin tahu, sikap positif dan kesadaran tentang adanya hubungan yang saling mempengaruhi antara sains, lingkungan, teknologi dan masyarakat, mengembangkan keterampilan proses untuk menyelidiki alam sekitar, memecahkan masalah dan membuat keputusan, meningkatkan kesadaran untuk berperan serta dalam memelihara, menjaga dan melestarikan lingkungan alam dan untuk meningkatkan kesadaran untuk menghargai alam dan segala keteraturannya sebagai salah satu ciptaan Tuhan.

Praktikum masih jarang dilakukan oleh para guru. Dalam 1 semester sebanyak $22 \%$ (sebagian kecil) guru tidak pernah melakukan praktikum, $59 \%$ (sebagian kecil) guru melakukan 1 kali praktikum, $13 \%$ (sebagian kecil) guru melaksanakan 2-3 kali praktikum, 6\% (sebagian kecil) guru melaksanakan 4-5 kali praktikum, dan tidak ada guru yang melaksanakan praktikum lebih dari 5 kali dalam 1 semester.

$$
\text { Sebanyak } 75 \% \quad \text { (hampir }
$$
seluruhnya) guru menyatakan bahwa guru merasa kesulitan dalam melaksanakan praktikum. Selanjutnya pertanyaan mengenai kesulitan guru pada saat praktikum juga diperjelas dengan wawancara. Adapun jawaban hasil wawancara mengenai kendala dalam melaksanakan praktikum disajikan pada grafik 2 di bawah ini.

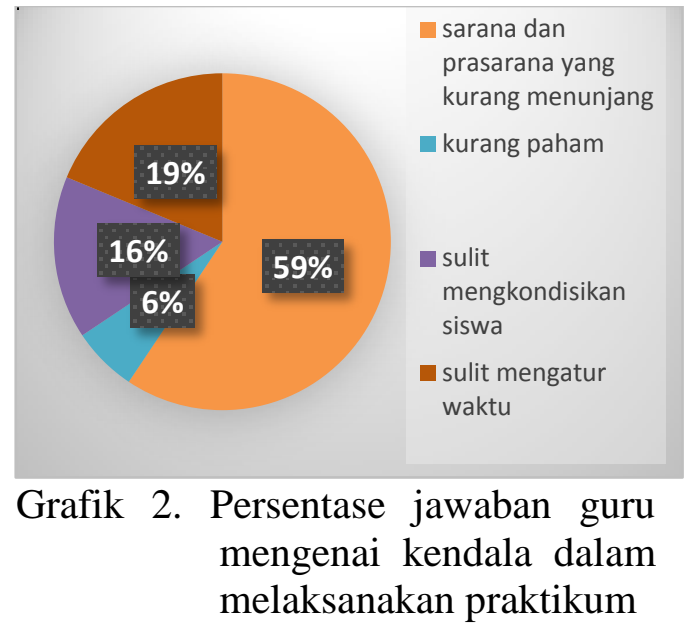

Alasan jarangnya praktikum yang terungkap dari hasil kuosioner disebabkan karena beberapa hal antara lain persiapan praktikum, kurangnya penunjang praktikum, keterbatasan waktu, serta sulit mengkondisikan siswa. Namun alasan yang paling banyak dikemukakan guru baik dalam kuosioner maupun jawaban wawancara dikarenakan kurangnya sarana penunjang praktikum antara lain laboratorium serta alat dan bahan. Kemudian setelah dikaitkan dengan materi yang dipraktikumkan oleh sebagian besar guru merupakan materi praktikum yang memerlukan alat dan bahan yang cukup mahal. Penemuan ini sesuai dengan hasil penelitian yang diungkap oleh Thair \& Treagust (1997) bahwa kesulitan yang dihadapi guru untuk melakukan praktikum cukup kompleks mulai dari sedikitnya waktu, alat dan bahan yang kurang serta tidak adanya bantuan (laboran). Senada juga dengan temuan penelitian rendahnya pelaksanaan pembelajaran sains melalui kerja praktek di laboratorium antara lain kurangnya ketersediaan sarana (Klainin dalam Fensham, 1988), 
rendahnya kemampuan (MuwangaZake, 2005) dan kemauan guru.

Pernyataan dari salah seorang guru berdasarkan hasil wawancara "Saya tidak paham sepenuhnya mengenai kegiatan praktikum IPA, karena guru SD tidak sama dengan guru SMP atau SMA yang sudah dikhususkan pada pembelajaran IPA (baik fisika, kimia dan biologi) sehingga melaksanakan praktikum terasa menyulitkan bagi saya (G10)". Kekurangpahaman guru dalam praktikum pernah diungkap dalam penelitian Supriatno (2013) bahwa guru-guru sains memiliki kemampuan prosedural yang rendah. Begitupun yang disampaikan pada penelitian. Maulina (2014) bahwa berdasarkan hasil uji kemampuan guru dalam melakukan praktikum masih rendah yang disebabkan rendahnya pemahaman guru dalam implementasi praktikum.

$\begin{array}{cc}\text { Aktivitas } & \text { belajar di } \\ \text { laboratorium } & \text { memerlukan }\end{array}$
perancangan kegiatan yang baik yang akan membantu guru dalam melaksanakan praktikum. Perancangan ini termasuk juga dalam merancang LKS, penggunaan alat dan bahan, pengaturan kelompok siswa, dan aspek penilaian agar praktikum berjalan lancar. Hasil wawancara mengungkap kesulitan guru dalam pengelolaan kelas. "Saat praktikum karena semua dilakukan oleh guru sendiri, terkadang siswa sulit dikondisikan sementara guru juga harus mempersiapkan segala sesuatunya sendiri (G13). Jika guru mempersiapkan dengan baik terutama dalam perancangan praktikum bisa dipastikan pengelolaan kelas akan dapat dilaksanakan dengan baik.
Dalam hal materi praktikum sebanyak 63\% (sebagian besar) guru mempraktekkan materi fisika sederhana (mengenai gaya, magnet, listrik dan energi), $12 \%$ (sebagian kecil) materi kimia (materi dan perubahan sifat), dan $25 \%$ (sebagian kecil) materi biologi (paru-paru dan sistem transport pada batang. Mengenai praktikum berdasarkan masalah yang siswa temukan pada kehidupan sehari-hari sebagian kecil guru $(6 \%)$ menyatakan pernah dan hampir seluruh guru (97 \%) menyatakan tidak pernah. Wawancara selanjutnya dilakukan terkait dengan kesulitan guru dan materi praktikum dengan memberikan alternatif praktikum yang sederhana yang dekat dengan keseharian siswa (berbasis konteks). Hasil wawancara disajikan pada grafik 3 .

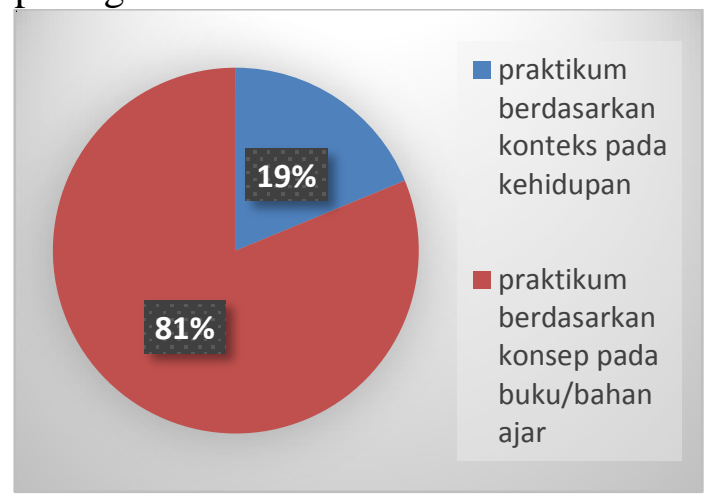

Grafik 3. Persentase jawaban guru dalam Pemilihan materi praktikum

Salah satu pernyataan guru mengenai kegiatan praktikum berbasis konteks pada kehidupan sehari-hari, "Dalam pemikiran saya praktikum di laboratorium dengan menggunakan alat dan bahan yang lengkap (G1)". Jawaban yang lainnya Saya sebelumnya tidak terfikir bahwa praktikum bisa dilakukan dengan mengajak siswa pada masalah yang siswa temui di kehidupan sehari hari 
(G32). Pada saat melaksanakan praktikum guru hanya terfokus pada konsep, padahal jika dihubungkan dengan tahap perkembangan kognitif Piaget sebetulnya siswa SD kelas 4 dan 5 berada pada tahap operasional konkret yang akan mampu memecahkan permasalahan yang dekat dengan konteks yang sering ditemukan sehari-hari (Suparno, 2001). Secara sederhana maksud dari pendekatan berbasis konteks adalah dengan mengajak siswa ke dalam apa yang mereka rasakan dan apa yang mereka lihat setiap hari dalam kehidupan.

Konteks akan membantu guru untuk mengaitkan materi yang dipelajari dengan dunia siswa atau situasi/kondisi dimana pembelajaran itu terjadi. Diawali dari pertanyaan yang meaningful (bermakna). Contoh Praktikum berbasis konteks misalnya bisa dilakukan mengenai perubahan cuaca yang semakin panas untuk siswa kelas 5 pada KD 3.3. Mengidentifikasi perubahan yang terjadi di alam, hubungannya dengan penggunaan sumber daya alam dan pengaruh kegiatan manusia terhadqap keseimbangan lingkungan sekitar. Praktikum diawali dari suatu pertanyan "Mengapa cuaca semakin panas?", selanjutnya siswa diajak untuk keluar kelas, merasakan cuaca panas sebagai kegiatan merasakan masalah, selanjutnya dengan modal pertanyaan yang harus dijawab dan fenomena yang telah dirasakan siswa diajak untuk melakukan percobaan dengan alat yang sederhana membandingkan suhu udara menggunakan thermometer antara gelas yang tertutup rapat dengan gelas yang dibiarkan terbuka, untuk selanjutnya siswa diajak mengaitkan materi pemanasan global dalam konsep yang sederhana.

Konteks dalam kehidupan sangat banyak tinggal bagaimana guru kreatif dalam merancang praktikum. Begitupun penggunaan alat dan bahan tidak harus selalu mahal tetapi cukup dengan apa memanfaatkan yang siswa dapat temukan di sekita mereka (rumah dan sekolah). Terlebih dalam pembelajaran IPA dimana sebagian besar objek yang dikaji adalah makluk hidup dan lingkungan sekitar yang bisa dimanfaatkan dengan maksimal.

Mengenai literasi sains sebanyak $28 \%$ (hampir separuhnya) guru tidak paham tentang literasi sains. Wawancara juga mempertanyakan bagaimana pemahaman guru tentang literasi sains dan kaitannya dengan praktikum. Beberapa jawaban praktikum seperti diungkap di bawah ini."Saya sedikit paham tentang literasi sains, namun tidak mengetahui secara mendalam (G5)".

Menggunakan pengetahuan ilmiah, mengidentifikasi pertanyaan dan menarik kesimpulan berdasarkan fakta untuk memahami alam semesta dan membuat keputuan dari perubahan yang terjadi karena aktivitas manusia adalah nyawa dari literasi sains. Berdasarkan penelitian ini sebagian besar guru belum paham mengenai literasi sains. Padahal setiap individu sangat perlu memerlukan pengetahuan ilmiah yang cukup sehingga mereka mampu berfikir secara ilmiah tentang masalah yang akan dihadapi di kehidupan selanjutnya.

Literasi sains sangat penting untuk dikuasai oleh semua warga negara (Rutherford \& Alhgren, 2000). 
Kemampuan literasi sains suatu negara berhubungan erat dengan tingkat ekonomi di negara tersebut (Phearson, 2008). Jika semua mampu berliterasi sains tentunya akan mampu mnenyuplai ilmuwan-ilmuwan yang handal untuk kemajuan suatu negara, minimal jika setiap individu berliterasi sains minimal akan mampu membaca kondisi perubahan yang ada sehingga lebih peduli terhadap bumi dan lingkungannya.

Adapun acuan guru untuk melaksanakan praktikum adalah hampir separuhnya berasal dari buku teks dan LKS (42\%) dan dari penerbit (35\%), hanya sebagian kecil guru yang memakai acuan dari internet (17\%) dan menyusun sendiri LKS (6\%). Dalam menunjang pembelajaran sains acuan perlu memperhatikan karakteristik peserta didik. Buku teks dan LKS yang ada di pasaran belum tentu sesuai dengan kondisi siswa. Guru kreatif sebaiknya mampu menyusun LKS sendiri yang mampu mencerminkan karakteristik materi yang akan diajarkan.

Berdasarkan hasil penelitian yang telah diungkap bahwa kegiatan praktikum berbasis konteks dalam rangka melatihkan literasi sains cenderung masih rendah. Penelitian juga mengungkap bahwa praktikum konvensional pun cenderung masih jarang dilaksanakan.

Dalam upaya mencapai tujuan pembelajaran sains ini praktikum merupakan metode yang paling tepat. Mengingat bahwa kegiatan pembelajaran sains bukan hanya pemaparan pengetahuan, maka harus direncanakan proses yang melibatkan siswa untuk aktif menemukan pengetahuan (process objectives). Pengalaman langsung yang lebih dikenal dengan learning by doing, akan memberikan kesan paling utuh dan paling bermakna mengenai informasi dan gagasan yang terkandung karena melibatkan indera penglihatan, pendengaran, peraba, penciuman dan pengecapan. Hal ini sangat penting karena karakteristik dari IPA merupakan proses inkuiri. Pembelajaran praktikum merupakan kegiatan yang melibatkan seluruh aktivitas, kreativitas, dan intelektualitas siswa (Rustaman, 1995). Praktikum akan mampu meningkatkan antusiasme terhadap sains, melatih keterampilan berfikir dan menghadapi masalah, serta berlatih menanamkan sikap positif pada diri siswa. Sangat penting bagi siswa untuk belajar bagaimana cara mengaplikasikan sains dibandingkan mempelajari realitas, konsep, generalisasi, teori dan hukum sains. Terdapat banyak bukti dan klaim bahwa kegiatan praktikum yang tepat dapat meningkatkan sikap kritis, sikap ilmiah dan keterampilan proses sains siswa.

Kesulitan guru dalam melaksanakan praktikum berbasis konteks yang mampu melatihkan literasi sains dianggap cukup wajar, karena seperti yang diungkap dalam Hilman (2015) bahwa guru SD adalah guru borongan. Perlu untuk memberikan pemahaman sekaligus pelatihan literasi sains bagi guru SD sebagai agen utama yang akan melatihkan literasi sains di usia dini.

\section{SIMPULAN DAN SARAN}

Simpulan dari penelitian ini berdasarkan hasil kuosioner adalah guru menganggap praktikum penting untuk dilaksanakan (100\%) namun sebagian besar guru masih jarang 
melaksanakan praktikum (82\%) dan merasa kesulitan dalam melakukan praktikum $(75 \%)$ terutama karena terbatasnya fasilitas di sekolah (59\%) sulitnya mengkondisikan siswa $(22 \%)$, sulit dalam mempersiapkan $(33 \%)$ dan waktu yang terbatas $(6 \%)$. Adapun berdasarkan hasil wawancara terungkap bahwa guru cenderung memahami praktikum sebagai kegiatan yang dilaksanakan di laboratorium yang memerlukan peralatan laboratorium standar yang harganya mahal. ini memperlihatkan bahwa perspektif guru terhadap kegiatan praktikum dengan mengangkat konteks pada kehidupan sehari-hari siswa cenderung masih rendah dan belum mampu melatihkan literasi sains bagi siswa

\section{DAFTAR PUSTAKA}

Barker, V., \& Millar, R. (1999). Students reasoning about basic chemical reactions: What changes occur during a context-based post-16 chemistry course? International Journal Science Education, Vol. 21, No.6, 645665.

Bennett, J., \& Lubben, F. \& Hogarth, S. (2006). Bringing science to life: A synthesis of the research evidence on the effects of context-based and sts approaches to science teaching. Science Education, Vol. 91, No.3, 347-370.

Brotheron \& Preece. (2006). Science Process Skills: Their Nature And Interrelationships. Research in Science \& Technological Education .
Retrieved Juli 1, 2016, from http://www.tandfonline.com/d oi/abs/10.1080/026351495013 0101

Fensam, Peter (1988). Development and Dilemmas in Science Education. London. The Falmer Press.

Harlen, W. (1999). 'Purposes and procedures for assessing science process skills", Assessment in Education, Vol.6, No.1, 129-144.

Hilman, I. (1995). Mungkinkah Membangun Literasi Sains di SD/MI dengan Kompetensi Guru di Indonesia. Prosiding: Seminar Nasional "Membangun Imajinasi dan Kreativitas Anak melalui Literasi”. Program studi PGSD PPS UPI.

Hodson, D. (1993). Teaching and learning about science: considerations in the philosophy and sociologyof science London: The Open University.

Koentjaraningrat. (1994). MetodeMetode Penelitian Masyarakat. Jakarta: Gramedia.

Köse, E., \& Tosun, F. (2011). Effect of context based learning in students achievement about nervous system. Journal of Turkish Science Education, Vol.8, No.2, 91-106. 
32 Jurnal Pendidikan Matematika dan IPA Vol. 8. No. 1. Januari 2017: 23-33

Maulina, Dina. (2014). Profil Kemampuan Guru-Guru IPA se-Bandar Lampung dalam Melakukan Kegiatan Praktikum. Retrieved September 14, 2016, from http://download.portalgaruda. org/article.php? article $=28808$ $4 \&$ val $=7233 \&$ title $=$ profil $\% 20$ kemampuan $\% 20$ guruguru $\% 20 \mathrm{ipa} \% 20 \mathrm{smp} \% 20$ sebandar\%20lampung\%20dalam $\% 20$ melakukan\%20kegiatan\% 20praktikum

Muwange, Johnnie W.F \& Zake. (2005). Is Science Education in a Crisis? Some of the problems in South Africa. Retrieved Agustus 15, 2016, from http://www.sciecnein africa.co.za/scicrisis.htm

Norris, S. P., \& Phillips, L. M. (2003). How literacy in its fundamental sense is central to scientific literacy. Science Education Journal, Vol.87, 224-240.

OECD. (2009). PISA 2009 Assessment Framework. Key Competencies in Reading, Mathematics.and

Science.Organisation for Economic Co-operation \& Development \&Unesco Institute for Statistics.

OECD. (2013). PISA 2009 Result. Executive Summary. Organisation for Economic Co-operation \& Development \& Unesco Institute for Statistics.
Phearson, P.T.; Pollack, G.R.; and Sable, J.E. (2008). Increasing scientific literacy in undergraduate education: Acase study from "frontiers of science" at Columbia University.

Ramsden, M. J. (1997). How does a context-based approach influence understanding of key chemical ideas at 16+?.International Journal of Science Education, Vol.19 No.6, 697-710.

Rustaman. (1995). Strategi Belajar Mengajar. Malang: UM.

Rustaman. (2011). Pendidikan dan Penelitian Sains dalam Mengembangkan

Keterampilan Berfikir Tingkat Tinggi untuk Pembangunan Karakter. Bandung: FPMIPA UPI.

Rutherford \& Alhgren. (2000). Science for All America. Retrieved Agustus 17, 2015, from http://www. project2016. org

Suparno. (2001). Teori Perkembangan Kognitif Jean Piaget. Yogyakarta: Kanisius.

Supriatno, Bambang. (2013), Pengembangan Program Perkuliahan Pengembangan Praktikum Biologi Sekolah Berbasis Ancorb untuk Mengembangkan Kemampuan Merancang dan Mengembangkan Desain Kegiatan Laboratorium. 
Pembelajaran IPA dengan Praktikum 33

Disertasi. Universitas Pendidikan Indonesia.

Thair, M and Treagust, D. F. (1997).

A Review of Teacher

Development Reforms in
Indonesian Secondary

Science: The Effectiveness of Practical Work in Biology.

Research in Science

Education, Vol.27, No.4, 581597. 